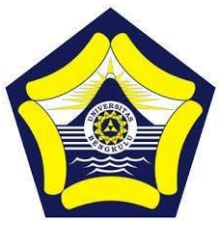

JOLL 4 (2) (2021)

Journal of Lifelong Learning

\title{
Analisis Tentang Pengembilan Keputusan Dalam Memilih Program Prodi Pendidikan Nonformal
}

\author{
Muthia', Rufran Zulkarnain $^{2}$ \\ Pendidikan Nonformal Universitas Bengkulu \\ muthia1702@gmail.com, rufran@unib.ac.id
}

\begin{abstract}
Abstrak
Tujuan dari penelitian ini adalah untuk mengetahui seberapa besar pengaruh faktor orang tua, faktor teman sebaya, faktor citra perguruan tinggi, dan faktor prospek pekerjaan dalam pengambilan keputusan memilih program studi Pendidikan Nonformal FKIP Universitas Bengkulu. Jenis penelitian ini adalah Kuantitatif. Penelitian ini dilakukan dengan metode analisis deskriptif dan analisis faktor, sedangkan yang menjadi informan penelitian adalah mahasiswa Prodi Pendidikan Nonfromal FKIP UNIB angkatan 2017-2020 berjumlah 53 mahasiswa. Teknik pengumpulan data menggunakan kuesioner yang disebar pada mahsiswa PNF angkatan 2017-2020. Hasil penelitian menunjukkan bahwa Faktor orang tua memiliki tingkat pengaruh sebesar 70,26\% ,faktor teman sebaya memiliki tingkat pengaruh sebesar 54\%, faktor citra perguruan tinggi memiliki tingkat pengaruh sebesar 88,18\%, dan faktor Prospek Pekerjaan dengan tingkat pengaruh sebesar $81,58 \%$.
\end{abstract}

Kata kunci : Faktor - faktor yang mempengarahui, Pengambilan

\begin{abstract}
Purpose of this study was to determine how much influence the factors of parents, peer factors, college image factors, and job prospects factors in making decisions to choose FKIP Non-formal Education study programs Bengkulu University. This type of research is quantitative. This research was conducted using descriptive analysis methods and factor analysis, while the informants of the research were the students of the 2017-2020 FKIP UNIB Non-formal Education Study Program, totaling 53 students. The data collection technique used a questionnaire that was distributed to PNF students class 2017-2020. The results showed that the parent factor has an influence level of $70.26 \%$, the peer factor has an influence level of 54\%, the college image factor has an influence level of $88.18 \%$, and the Job Prospects factor with an influence level of $81.58 \%$.
\end{abstract}

Keywords: Departmental Decision Making, College Image

\section{PENDAHULUAN}

Pendidikan merupakan faktor utama dalam pembentukan pribadi manusia. Melalui pendidikan diharapkan bakat dan keterampilan dapat dikembangkan secara maksimal, dengan memperoleh pendidikan secara tidak langsung seseorang berusaha mengembangkan dirinya agar memperoleh berbagai pegetahuan seperti prinsip, teori, inovasi, krarivitas dan tanggungjawab.

Dalam Undang-Undang RI Nomor 20 Tahun 2003 di kemukakan bahwa, "Pendidikan formal adalah jalur pendidikan yang terstruktur dan berjenjang yang terdiri 
atas pendidikan dasar, Pendidikan mengengah, dan Pendidikan tinggi. Selanjutnya, dalam Undang-Undang Nomor 12 Tahun 2012 dikemukakan bahwa "Pendidikan tinggi adalah jenjang pendidikan setelah pendidikan menengah yang mencakup program diploma, program sarjana, program magister,program doktor, dan program profesi, serta program spesialis, yang diselenggarakan oleh perguruan tinggi berdasarkan kebudayaan bangsa Indonesia”.

Setelah seseorang menyelasaikan/lulus pada jenjang pendidikan menengah atas baik SMA maupun SMK pasti dihadapkan pada suatu pilihan yaitu melanjutkan pendidikan pada jenjang pendidikan tinggi atau langsung terjun pada dunia kerja. Tidak mudahnya dalam menentukan keputusan jurusan yang sesuai dengan diri, menjadikan banyak mahasiswa yang mengalami salah jurusan. Kenyataan dilapangan menujukan bahwa adanya suatu permasalahan bahwa banyak sekali mahasiswa yang salah dalam memilih jurusan.

Kesesuaian keputusan jurusan yang dibuat berdasarkan kemampuan yang dimiliki akan mempermudah mahasiswa dalam meraih kesusksesan di masa depan. Menurut Prajudi Atmosudirjo (2004:23) Keputusan adalah suatu pengakhiran dari pada proses pemikiran tentang suatu masalah dengan menjatuhkan pilihan pada suatu alternatif.

Secara umum banyak faktor yang melatarbelakangi keputusan untuk menetukan pilihanya dalam memilih jurusan. Berbagai faktor yang dipertimbangkan tersebut antara lain biaya pendidikan, reutasi perguruan tinggi, citra program studi, perospek pekerjaan, lingkungan, minat, motivasi, dan keberhasilan alumni. Menurut Mehboob et al (2012) dalam jurnal penelitian
Rizqi Amaliya(2019:37), menjelaskan bahwa Faktor yang mempengaruhi dalam memilih perguruan tinggi antara lain faktor aspirasi sikap, bimbingan karir, program akademik, biaya pendidikan, lokasi, reputasi perguruan tinggi, promosi, fasilitas, ketersediaan bantuan keuangan dan faktor orang tua.

Selain itu menurut Mappiare (1982) dalam jurnal penelitian Karina M Brahmana (2010: 51), dalam menetapkan pilihan jurusan di perguruan tinggi, pada umumnya ada beberapa faktor yang ikut mempengaruhi remaja akhir dalam menetapkan pilihan, seperti minat remaja akhir, aspirasi remaja akhir, minat orang tua, aspirasi orang tua serta kesan-kesan ( menyakut gengsi) dari teman-teman sebaya remaja yang bersangkutan.

Namun demikian tentu ada beberpa aspek saja yang kemungkinan besar berpengaruh pada pengambilan keputusan mahasiwa seperti faktor orang tua, faktor teman sebaya, faktor citra perguruan tinggi, dan faktor prospek pekerjaan.

Universitas Bengkulu ( UNIB) merupakan salah satu Universitas yang ada di Provinsi Bengkulu. Berdiri pada tanggal 24 April 1982 berdasarkan keputusan Presiden RI Nomor 17 tahun 1982 dan diresmikan oleh Mentri Pednidikan dan Kebudayaan Republik Indonesia. Prof. Dr. Daud Yusuf. Universitas Bengkulu memiliki delapan fakultas yaitu Fakultas Pertanian, Fakultas Ekonomi dan Bisnis, Fakultas Ilmu Sosial dan Ilmu Politik (ISIP), Fakultas Hukum, Fakultas Keguruan dan Ilmu Pendidikan (KIP), Fakultas Matematika dan Ilmu Pengetahuan Alam, Fakultas Teknik, dan Fakultas Kedokteran dan Kesehatan serta Program Pascasarjana. Salah satu program studi yang ada di Universitas Bengkulu adalah Prodi Pendidikan Nonformal FKIP Univesitas Bengkulu. 
Penelitian ini berfokus pada faktorfaktor yang mempengaruhi keputusan mahasiswa dalam memilih perguruan tinggi ,khususnya mahasiswa Prodi Pendidikan Nonformal FKIP Universitas Bengkulu angkatan 2017-2020. Faktor orang tua, faktor teman sebaya, faktor citra perguruan tinggi dan faktor prospeke pekerjaan memiliki pengaruh terhadapat keputusan mahasiswa memilih Prodi pada mahasiswa Pendidikan Nonformal FKIP Universitas Bengkulu. Oleh karena itu peneliti tertarik untuk melakukan penelitian dengan judul “ Analisis tentang Pengambilan Keputusan dalam memilih Prodi oleh mahasiswaPendidikan Nonformal FKIP Universitas Bengkulu”.

\section{METODE}

Jenis penelitian deskriptif kuantitatif untuk mencapai tujuan penelitian. Menurut Sugiyono ( 2015:8), metode penelitian kuantitatif merupakan : Metode penelitian yang berlandasankan pada filsafat positivism, digunakan untuk meneliti pada populasi atau sampel tertentu, teknik pengambilan sampel pada umumnya dilakukan secara random, pengumpulan data menggunakan instumen penelitian, analisis data bersifat kuantitatif/statistic dengan tujuan untuk menguji hipotesis yang telah ditetapkan.

Populasi pada penelitian ini adalah mahasiswa prodi Pendidikan Nonformal FKIP Universitas Bengkulu angkatan 2017, 2018, 2019, dan 2020 dengan jumlah 213 mahasiswa. Peneliti mengambil sampel dari populasi sebesar $25 \%$ yaitu 53 mahasiwa. . Menurut arikunto (2006:134) menjelaskan bahwa apabila subyeknya kurang dari 100, maka subyek diambil semua, tetatpi jika jumlah subyeknya besar ( lebih dari 100 ) dapat diambil antara $10-15 \%$ atau $20-25 \%$ atau lebih.

Teknik pengumpulan data yang digunakan dalam penelitian jni adalah kusioner (angket). Penyebaraan angket menggunakan google from yang di sebarkan melalui media sosial dan penyebaran secara langsung kepada mahasiswa yang diukur menggunakan skala likert.

\section{Teknik Analisis Data}

Teknik analisis data penelitian merupakan salah satu langkah yang sangat penting dalam proses penelitian karena disana hasil penelitian akan tampak. Setelah semua data terkumpul, langkah selanjutnya adalah menganalisis data, sehingga data-data tersebut dapat ditarik kesimpulan, teknik analisis data dalam penelitian ini adalah teknik analisis deskriptif dianalisis menggunakan Software Microsoft Excel 2010 dengan rumus sedangkan perhitungan dalam angket menggunakan presentanse, dengan rumus sebagian berikut:

$$
\begin{aligned}
& \text { Persentase }(\%)=(\%)=\frac{n}{N} \times 100 \% \\
& \text { Keterangan : } \\
& \mathrm{n}=\text { Nilai yang diperoleh } \\
& \mathrm{N}=\text { Jumlah selutuh nilai } \\
& \%=\text { Tingkat Presentase }
\end{aligned}
$$

Untuk mengetahui tingkat kriteria tersebut, selanjutnya skor yang dipeoleh (dalam \%) dengan analisis deskriptif persentase dikonsultasikan dengan tabel kriteria. Untuk megetahui tingkat kriteria terebu, selanjutnya skor yang diperoleh (dalam \%) dengan analsiis deskriptif persentase dikonsultasikan dengan tabel kriteria. Cara menetukan presentase tertiggi dan terendah telebih dahulu menggunakan rumus sebagai berikut :

\begin{tabular}{|l|l|}
\hline \multicolumn{1}{|c|}{ Prensetase } & \multicolumn{1}{c|}{ Kriteria } \\
\hline $20 \%-36 \%$ & Sangat Tidak Baik \\
\hline $36 \%-52 \%$ & Tidak Baik \\
\hline $52 \%-68 \%$ & Cukup \\
\hline $68 \%-84 \%$ & Baik \\
\hline $84 \%-100 \%$ & Sangat Baik \\
\hline
\end{tabular}

\section{HASIL DAN PEMBAHASAN}

Penelitian ini dilakukan pada mahasiswa Prodi Pendidikan Nonformal FKIP Universitas Bengkulu. Teknik analisa yang 
digunakan adalah teknik analisa deskriptif presentase.

Ada pun hasil pengelolaan data dari ke 4 faktor, yaitu :

\section{a. Faktor Orang tua mempengrauhi keputusan mahasiswa memilih Prodi Pendidikan Nonformal FKIP UNIB}

Hasil pengelolaan data yang di dapatkan terlihat bahwa faktor orang tua memiliki pengaruh sebesar $\mathbf{7 0 , 2 6} \%$ dengan tingkat pengaruh yang Baik terhadap pengambilan keputusan mahasiswa dalam memilih Program Studi Pendidikan Nonformal FKIP Universitas Bengkulu. Hal ini menujukkan bahwa orang tua sangat peduli dengan pendidikan anaknya.

Keluarga merupakan sosok yang terdekat bagi setiap orang. Keluarga juga merupakan salah saatu penentu dalam hidup setiap orang, termasuk keputusan keluarga menjadi salah satu pertimbagan yang paling utama bagi setaip individu untuk memutuskan sesuatu.

Dalam keluarga yang paling berpengaruh biasanya adalah orang tua. Orang tua merupakan orang yang mengatur, medidik dan mendukung anaknya, juga sebagai orang terdekat dengan anaknya. Orang tua dapat menjadi patokan dan pertimbangan utama anaknya untuk melakukan sesuatau. Pilihan dan dukungan orang tua selalu dijadikan oleh anak sebagai pertimbangan penting untuk memilih sesuatau. Meskinpun tidak semua anak mengikuti pilihan orang tunya, namaun sebagai besar anaka senantiasa menjadikan orang tuanya sebagai sososk yang harus diaati dan harus diikutu sebagai wujud baktinya kepada orang tua. Orang tua dengan peranperannya dalam keluarga akan membantu anaknya untuk mengatasi masalah.

Dukungan sosial yang tinggi dri orang tua atau keluarga yang besar dapat meningkatkan kemampuan menentukan keputusan memilih Program Studi di perguruan tinggi, sehingga hal ini mahasiswa dapat menghadapi kesuliitan atau permasalan dipegururan tinggi. Menurut ( Cutrona,2004) dukungan sosial orang tua ada;ah dororngan kenyamanan secara fisik dan psikologis yang diberikan oleh orang tua untuk mnyelesaikan maslah. Dukungan orang tua memiliki dampak yang besar terhadap mahaasiswa dari segi pendidikan maupun pekerjaan yang akan mereka pilih, dimana hal ini pengarahan dari orang tua menajdi sebuah bahan petimbangan.

Dukungan orang tua dapat mempengaruhi mahasiswa dalam semua tahap pengambilan keputusan. Dukungan tersebut dibutuhkan setiap mahasiswa dalam memutuskan rencana masa depanya. Saat mahasiswa merasa didukung dan dicintai oleh orang tua, mahasiswa memiliki lebih banyak keterampilan dalam berfikit tentang studi dan dunia kerja.

Menurut Covey (1997) dalam Yusuf (2009: 47-48), orang tua mempunyai beberapa peran dalam keluarga :

1) Sebagai Modeliling Orang tua menjadi contoh atau teladan baik untuk seorang anak baik dalam menjalakankan nila-nilai agama maupun norma yang ada pada masyarakat. Orang tua mempunyai pengaruh sangat kuat dalam kehidupan anak karena tingkah laku dan cara berpikir anak dalam kehidupan anak karena tingkah laku dan cara berpikir anak dibentuk oleh tingkah laku dan cara berpikir orang tuanya baik positif maupun negatif.

2) Sebagai Mentoring Orang tua adalah mentor pertama bagi anak yang menjalin hubungan, memberikan kasih sayang secara mendalam baik secara positif maupun negatif, memberikan perlindungan sehingga mendorong anak untuk bersikap terbuka dan mau menerima pengajaran.

3) Sebagai Organizing Orang tua mempunyai peran sebagai organizing yaitu mengatur, 
mengontrol, merencanakan, bekerja sama dalam menyelesaikan setiap permasalahan yang terjadi, meluruskan struktur dan system keluarga dalam rangka membantu menyelesaikan hal-hal yang penting serta memenuhi semua kebutuhan keluarga.

4) Sebagai Teaching Peran orang tua sebagai teaching adalah menciptakan conscious competence pada diri anak yaitu mereka mengalami tentang apa yang mereka kerjakan dan alasan tentang mengapa mereka mengerjakan itu.

Dari pendapat diatas diketahui bahwa apabila orang tua dapat memahami perannya sebagai orang tua maka orang tua akan memberikan kebebasan kepada anaknya untuk mengambil keputusan dan orang tua mendukung setiap keputusan yang diambil oleh sianak, sehingga anak akan mengambil keputusan sesuai dengan keinginan, minat dan bakat yang dimiliki dan pada akhirnya anak akan menjalankan segala sesuatunya dengan senang dan tanpa beban.

Dalam hal ini orang tua sangat mendukung setiap keputusan yang akan diambil oleh anaknya. Dukungan orang tua dapat dilihat dari dukungan materil maupun dukungan moril. Dimana semakin besar pengaruh orang tua, maka keputusan memilih Prodi Pendidikan Nonfromal FKIP Universitas Bengkulu semakin besar.

Berdasarkan konsep yang ada, dukungan dari orang tua berpengaruh terhadap keputusan memilih Program Studi Pendidikan Nonformal Universitas Bengkulu.

\section{b. Faktor Teman Sebaya mempengrauhi keputusan mahasiswa memilih Prodi Pendidikan Nonformal FKIP UNIB}

Hasil peneglolaan data yang di dapatkan terlihat bahwa faktor teman sebaya memiliki pengaruh sebesar $54 \%$ dengan tingkat pengaruh yang Cukup terhadap pengambilan keputusan mahasiswa dalam memilih prodi Pendidikan Nonformal FKIP Universitas Bengkulu.

Kehidupan seseorang tidak selalu dipengaruhi oleh lingkungan keluarga saja. Pergaulan dianggap sangat berpengaruh terhadap seseorang baik dalam kepribadian ataupun pengambilan keputusan. Didalam pergaulan tentunya terdapat teman yang mmeounyai umur yang relative sama atau bisa disebut dengan teman sebaya.

Teman atau sahabat merupakan orag yang terdekat dengan setiap individu yang mempunyai teman. Orang yang memiliki teman, biasanya memiliki kesamaan salah satu kesamaanya adalah kesamaan umur, kesamaan sekolah, dan lain-lain. Teman merupakan salah atu sosok yang mempengaruhi individu karena biasanya seseorang labih luas meminta sosluasi denganya yakni teman/sahabat. Slah satunya mempengaruhi seseorang dalam memutuskan sesuatu.

Menurut Santrock (2007:205), Teman Sebaya adalah anak-anak dengan tingkat kematangan atau usia yang kurang lebih sama. Sedangkan menurut Usman ( 2013:58), Kelompok teman sebaya adalah sekelompok teman yang mempunyai ikatan emosional yang kuat dan siswa dapat berinteraksi, bergaul, bertukar pikiran, dan pengalaman dalam memberikan perubahan dan pengembangan dalam kehidupan sosial dan pribadinya. Teman sebaya tidak terbatas pada gender tertentu. Bahkan seringkali ditemukan grup sebaya yang anggotanya lintas gender. Dalam satu grup yang cukup besar terdiri dari anak laki-laki dan perempuan dengan rentang usia dan kedewasaan yang relatif sama. Hubungan demikian sudah dilakukan sejak seseorang lahir dan akan terus berlanjut. Melalui hubungan - hubungan dengan teman sebaya orang akan melakukan berbagai hal yang menjadi keyakinan bersama.Fungsi dari teman sebaya adalah memberikan informasi, dukungan, dan perhatian.

Hal ini menunjukan bahwa teman sebaya merupakan salah satu lingkungan 
terdekat dari seseorang dimana seseorang dapat mengutarakan sesuatu dengan bebas dan hal yang disampaikan oleh teman sebaya akan dianggap sesuatu yang dapat dipercaya sehingga dapat menjadi pertimbangan dalam pengambilan keputusan.

Mahasiswa yang memiliki dukungan yang cukup dari teman seabaya mendapatkan penguatan diri dalam mempertanggungjawabkan setiap keputusan yang diambil, seperti keputusan memilih Program Studi Pendidikan Nonformal FKIP Universitas Bengkulu.

Menurut Gottman dan Parker ( dalam Santrock, 2003:227), teman sebaya memiliki fungsi, anatar lain : (1) kebersaman:(2) stimulasi, seperti memberikan informasi yang menarik dan menyenangkan; (3) dukungan fisik, seperti memberikan waktu, kemampuankemampuan, dan pertolongan; (4) dukungan ego, seperti memberikan harapan, dorongan, dan umpan balik yang membantu remaja untuk mempertahankan kesan atas dirirnya sebagai individu yang mampu, menarik, dan berharga; dan (5) perhatian, seperti memberikan hubungan yang hangat,dekat,dan saling percaya dengan teman yan g lain.

Dalam hal ini teman sebaya pun mempunyai peran dalam mengambil keputusan pemebelian yaitu, teman sebaya memberikan kesemptan bagi anggotanya untuk mengisi peranana sosial yang baru, teman sebaya sebagai sumber informasi bagi teman yang lain, dan didalam teman sebaya, individu dapat mencapai kebebasab sendiri. Kebebasan di sini diartikan sebagai kebebasan untuk berpendapat, bertindak atau untuk menemukan idititas diri. Kerena dalam kelompok itu, anggota-anggota yang lain juga mempunyai tujuan dan keinginan yang sama yatitu memilih jurusan yang seesuai dengan mereka sukai.

Melalui dukungan teman sebaya, mahasiswa yang memiliki dukungan yang cukup dari teman sebaya mendapatkan penguatan kepercayaan diri dalam mempertanggungjawabkan setiap keputusan yang diambilnya, seperti keputusan memilih Program Studi Pendidikan Nonforma FKIP Universitas Bengkulu.

\section{c. Faktor Citra Perguruan Tinggi mempengrauhi keputusan mahasiswa memilih Prodi Pendidikan Nonformal FKIP UNIB}

Hasil pengolaan data yang di dapatkan terlihat bahwa faktor citra perguruan tinggi memiliki pengaruh sebesar $88,18 \%$ dengan tingkat pengaruh yang Sangat Baik terhadap pengambilan keputusan mahasiswa dalam memilih prodi Pendidikan Nonformal FKIP Universitas Bengkulu.

Citra merupakan gambaran subjektif yang dibuat oleh seseorang sebagai suatu hasil dari berbagai informasi serta persepsi terhadap sesuatua. Citra dapat berubah menajdi buruk atau negatif jika ternyata tidak didukung oleh kemampuan dan keadaan yang sesungguhnya. Sesorang mahasiswa saat akan menentukan jurusan yang ia pilih, maka secara bersamaan ia juga akan menentukan perguruan tinggi yang dia pilih, yang tentunya ia pandnag baik. Meskipun pada kenyataanya ada juga arahan dari orang lain agar memilih perguruan tinggi tersebut.

Menurut Bill Canton (S.Soemirat \& Adrianto. E 2007:111) mengatakan bahwa "citra adalah kesan, perasaan, gambaran dari publik terhadap perusahaan; kesan yang dengan sengaja diciptakan dari suatu objek, orang atau organisasi”.

Menurut Gonroos dalam Jasfar (2005) citra merupakan perwakilan penilaian dari konsumen, baik yang komsumen yang potensial maupun konsumen yang kecewa. Penilaian konsumen ini berbeda-beda, bisa penilaian antar individu maupun antar kelompok. Sedangkan menurut Bill Canton dalam S.Soemirat \& Adrianto. E (2007) memberikan pengertian citra sebagai apa yang terpikir, hasil dari perbuatan, gambaran diri publik terhadap perusahaan baik yang 
sengaja diciptakan dari suatu obyek, orang atau organisasi.

Sebuah citra perguruan tinggi yang kuat dan positif dalam semua aspek akan memiliki efek yang positif pada kinerja perguruan tinggi. Dengan demikian, citra perguruan tinggi dapat diartikan sebagai keyakinan berupa gambaran dan kesan umum akan suatu aspek yang dibentuk dengan memproses infomasi dari berbagai sumber setiap waktu.

Hal ini terlihat bahwa citra yang baik akan membuat masyarakat dan calon mahasiswa dan pihak lainnya menyukai suatu perguruan tinggi dikemudian hari. Dilihat dari latar belakangnya Universitas Bengkulu salah satu perguruan tinggi negeri yang ada di provinsi Bengkulu. Universitas Bengkulu berdiri pada tanggal 24 April 1982. Perguruan tinggi negri yang satu ini berlokasi di Jalan WR. Supratman, KAdang Limun, Benkulu. Universitas Bengkulu menepati urutan ke-50 sebagai Universitas terbaik di Indonesia pada tahun 2021. Univeritas Bengkulu diresmikan oleh Mentri Pendidikan Dan Kebudayaan berdasarkan Keppres Nomor 17 Tahun 1982. Setelah Uinb diresmikan, pada waktu yang sama dilantik Rektor UNIB yang pertama, yakni Prof. Ir. Soenjoto Sumodihardjo. Universitas Bengkulu mempunyai visi yaitu menjadi Universitas kelas dunia pada tahun 2025 dan mempunyai misi yaitu, mengembangkan pendidikan dan penelitian berkelas dunia, menghasilkan karya berstatus Hak atas Kekayaan Intelektual (HKI), melaksanakan pengabidian sesuai dengan kebutuhan masyarakat local, nasional, dan internasional, dan mengembangkan system tata kelola Universitas yang baik dan bersih.

Universitas Bengkulu memiliki delapan fakultas yaitu Fakultas Pertanian, Fakultas Ekonomi dan Bisnis, Fakultas Ilmu Sosial dan Ilmu Politik (ISIP), Fakultas Hukum, Fakultas Keguruan dan Ilmu Pendidikan (KIP), Fakultas Matematika dan Ilmu Pengetahuan Alam, Fakultas Teknik, dan Fakultas Kedokteran dan Kesehatan serta Program Pascasarjana. Salah satu program studi yang ada di Universitas Bengkulu adalah Pendidikan Non Formal yang merupakan bagaian dari Fakultass Keguruan dan Ilmu Pendidikan (KIP).

Fakultas Keguruan dan Ilmu Pendidikan merupakan salah satu Fakultas yang ada di Universitas Bengkulu. Sejak berdiri tahun 1982 FKIP UNIB telah menyelenggarakan program studi S1 Administrasi Pendidikan, Diploma 1 Pendidikan Matematika, Diploma 1 IPA dan Diploma 1 PMP. Fakultas KIP sendiri banyak menawarkan jurusan-jurusan yang ada. Fakultas KIP memiliki duabelas jurusan yakni Pendidikan Bahasa dan Sastra Indonesia, Pendidikan bahasa Inggris, Pendidikan Matematika, Pendidikan Biologi, Pendidikan Fisika, Pendidikan Guru Sekolah Dasar, Pendidikan Biologi, Pendidikan Kimia, Pendidikan Guru Pend. Anak Usia Dini, Pendidikan Penjaskes, Bimbingan dan Konseling, D3 Bahasa Inggris dan salah satunya Pendidikan Luar Sekolah Atau Pendidikan Nonformal. Dengan jumlah prodi yang banyak maka banyak mahasiswa yang tertarik.

Dari fakta diatas diketahui Universitas Bengkulu mampu membangun citra yang baik dalam pandangan masyarakat dan mahasiswa, ditambah lagi Universitas Bengkulu yang mempunyai pelayanan dalam penyelaggaraan pendidikan, seperti tenaga pengajar yang propesional, jajaran staf Universitas yang berdedikasi tinggi, fasilitas yang cukup baik, Universitas yang sduah terakreditasi “ B”, program-program studi yang banyak, dan lulusan-lulusan yang mampu berdaya saing di dalam dunia kerja.

\section{d. Faktor Prospek Pekerjaan mempengrauhi keputusan mahasiswa memilih Prodi Pendidikan Nonformal FKIP UNIB}

Hasil pengolaan data yang di dapatkan terlihat bahwa faktor prospek pekerjaan memiliki pengaruh sebesar $81,58 \%$ dengan tingkat pengaruh yang Baik terhadap pengambilan keputusan mahasiswa dalam memilih prodi Pendidikan Nonformal FKIP Universitas Bengkulu. 


\begin{abstract}
Setiap tahunnya seluruh Universitas di Indonesia akan banyak menghasilkan lulusan-lulusan sarjana dimana lulusan sarjana tersebut otomatis akan menjadi angkatan kerja baru. Angkatan kerja adalah mereka yan mempunyai pekerjaan, baik sedang bekerja maupun yang sementara tidak sedang bekerja karena suatu sebab, seperti petani uyang sedang menunggu panen, pegawai yang sedang cti, sakit, dan sebagainya. Disamping itu mereka yang tidak mempunyai pekerjaan tetatapi sedangmencari pekerjaan/ mengharrapkan dapat pekerjaan atau bekerja secara tidak optimal disebeut pengangguran.
\end{abstract}

Hal ini terlihat bahwa prospek pekerjaan menjadi pertimbangan karena setiap mahasiswa Prodi Pendidikan Nonformal FKIP Universitas Bengkulu akan memilih jurusan yang diketahui memiliki prospek pekerjaan yang jelas, karena mahasiswa ingin langsung bekerja segera setelah lulus. Dimana semakin besar kesempatan kerja, maka keputusan memilih jurusan Pendidikan Nonformal juga akan semakin besar.

Prospek pekerjaan merupakan peluang kerja bagi serang lulusan untuk menghasilkan barang atau jasa serta mendapatkan imbalan berupa upah atau gaji. Indikator yang digunakan dalam menilai prospek kerja adalah cita-cita, prospek kerja lulusan, masa studi , dan keberhasilan alumi. Suatu jurusan atau program studi memmpunyai prospek kerja yang bagus akan menjadi daya tarik bagi calon mahasiswa untuk memilih juruan atau program studi tersebut, sebaliknya apabila suatu jurusan atau program studi mempunyai prospek pekerjaan yang kurang maka calon mahasiswa akan berpikir dua kali untuk memilihnya.

Prospek di masa depan ( peluang kerja) merupakan suatu hal yang penting bagi setiap individu untuk memenuhi kebutuhnaya. Prospek di masa depan ( peluang kerja) adalah salah satu poin utama dalam tuntutan ekonomi yang menutut setiap individunya untuk bekerja pada pekerjaan atau profesi yang memilliki peluang besar.

Menurut kampus Besar Bahasa Indonesia prospek adalah kemungkinan atau harapan. Segala bentuk kejadian yang baik ataupun buruk yang kemungkinan akan terjadi.

Menurut Paul R. Krugman (2003:121), Prospek adalah peluang yang terjadi karena adanya usaha seseorang dalam memenuhi kebutuhan hidupnya juga untuk mendapatkan profit atau keuntungan. Selalin itu Menurut Siswanto Sutejo (1945:28), menyimpulkan secara jelas Prospek adalah suatu gambaran keseluruhan, baik ancaman ataupun peluang dari kegiatan pemasaran yang akan datang yang berhubungan dengan ketidakpastian dari aktifitas pemasaran atau penjualan. Lapangan kerja adalah keadaaan uang menggambarkan ketersediaan pekerjaaan untuk para pencari kerja. Pekerjaan adalah sebuah karir yang dilakukan dalam sebuah kehidupan yang menghasilkan sebuah karya bernilai imbalan dalam bentuk uang bagi seseorang.

Dengan demikian prospek pekerjaan merupakan kondisi yang akan dihadapi oleh seseorang dimasa yang akan dating baik kecendurangan untuk meningkatkan atau menutup. Kondidi ini dipengaruuhi oleh berbagai peluang da ancaman yang dihadapi. Kelemahan dan kekuatan yang dimiliki seseorang sehingga diperlukan perencanaan dan erumusan strar=tegis secara baik. Khususnya dalam peningkatan efisiensi dan kreativitas seseorang dalam mengolah hal-hal yang baru dengan memanfaatkan peluangpeluang dan mengetahui berbagai bentuk ancaman dikemudian hari.

Seseorang yang memilih melanjutkan pendidikanya ke perguruan tinggi untuk menunjang pekerjaan yang akan mereka pilih. Dengan demikian jurusan dengan prospek pkerjaan yang banyak menjadi tujuan dalam memilih jurusan. Hal ini dapat terlihat dalam penelitian ini menunjukan bahwa mahasiswa telah 
memikirkan prospek pekerjaan yang mereka inginkan. Melihat Program Studi Pendidikan Nonformal merupakan jurusan yang hanya ada di Universitas Bengkulu, karena itu mahasiswa memilihat prospek pekerjaan yang cukup besar di masa depan.

\section{KESIMPULAN}

Berdasarkan hasil analisis terhadap data yang diperoleh dari angket, diperoleh bahwa faktor-faktor yang mempengaruhi keputusan mahasiswa dalam memilih Program Studi Pendidikan Nonformal FKIP Universitas Bengkulu antara lain adalah faktor orang tua, teman sebaya, citra perguruan tinggi, dan prospek pekerjaan, maka dapat disimpulkan bahwa :

a. Faktor orang tua memiliki pengaruh sebesar 70,26\%, hal ini dapat dikatakan orang tua memiliki pengaruh yang baik untuk mempengaruhi keputusan mahasiswa Pendidikan Nonformal untuk memilih program studi di Universitas Bengkulu. orang tua akan mendukung secara material maupun moril setiap keputusan yang akan diambil oleh anaknya. Dengan dukungan inilha yang membuat mahasiswa akan lebih yakin dengan keputusan yang mereka pilih.

b. Faktor teman sebaya memiliki pengaruh sebesar $54 \%$, cukup memmpengaruhi keputusan. Hal ini menunjukan bahwa teman sebaya merupakan salah satu lingkungan terdekat dari seseorang dimana seseorang dapat mengutarakan sesuatu dengan bebas dan hal yang disampaikan oleh teman sebaya akan dianggap sesuatu yang dapat dipercaya sehingga dapat menjadi pertimbangan dalam pengambilan keputusan mahasiswa Prodi Pendidikan Nonformal dalam memilih Program Studi di Universitas Bengkulu.

c. Faktor citra perguruan tinggi memiliki pengaruh sebesar $88,18 \%$ sangat berpengaruh terhadap keputusan mahasiwa dalam memilih Program Studi. Hal ini berarti citra perguruan tiggi menjadi sesuatu hal yang penting bagi mahasiswa Prodi Pendidikan Nonformal FKIP Universitas Bengkulu pada saat memilih Program Studi untuk melajutkan perguruan tinggi. Citra yang terbentuk pada Universitas Bengkulu sangat diterima oleh masyarakat, mahasiswa maupun pihak lain.

Faktor prospek pekerjaan memiliki pengaruh sebesar $81,58 \%$ sangat berpengaruh terhadap keputusan mahasiswa dalam memilih Program Studi. Hal ini Hal ini terlihat bahwa prospek pekerjaan menjadi pertimbangan karena setiap mahasiswa Prodi Pendidikan Nonformal FKIP Universitas Bengkulu akan memilih jurusan yang diketahui memiliki prospek pekerjaan yang jelas, karena mahasiswa ingin langsung bekerja segera setelah lulus. Dimana semakin besar kesempatan kerja, maka keputusan memilih jurusan Pendidikan Nonformal juga akan semakin besarguna mengembangkan kualitas kehidupan ekonomi

\section{DAFTAR PUSTAKA}

Amaliya, Rizqi.2019. "Faktor-Faktor Yang Mempengaruhi Keputusan Mahasiswa Memilih Pendidikan Pada Program Studi Pendidikan Ekonomi FE UNY". Jurnal Pendidikan dan Ekonomi Vol 8, Nomor 1 (halaman 37). Yogyakarta: Universitas Negri Yogyakarta.

Arikunto. 2006. Proseedur Penelitian Suatu Pendektan Praktek. Jakarta : PT. Rineka Cipta.

Atmosudirjo, Prajudi dalam Hasan. (2004). Pokok-pokok Materi Teori Pengambilan Keputusan. Jakarta: Ghalia Indonesia.

Barhmana,M.Karina.2010.” Perbedaan Dalam Mempertimbangkan Faktor-Faktor Pengambilan Keputusan Pemilihan Jurusan Di Perguruan Tinggi Pada Remaja Akhir Yang Mempersepsikan Dirinya Diasuh Dengan Pola Asuh Yang Berbeda". Jurnal Universitas HKBP Nommensen Vol 18,Nomor 1 ( halaman 50-67). Medan : Universitas HKBP Nommensen 
Dasar-Dasar Public Relations. Rosdakarya, Bandung.

Cutrona, E. (2004). Handbook of social support communication in families. Lawrence Erlbaum Associates Publishers.

Jasfar, F. (2005). Manajemen Jasa Pendekatan Terpadu. Ghalia Indonesia, Bogor.

Krugman, P. R. and M. O. (2003). International Ecoonomic: Theory and Policy ( $6^{\text {th }}$ Edition). Pearson Education

Santrock, John W. 2007. Perkembangan Anak. terj. Mila Rachmawati \& Anna Kuswanti. Jakarta: Erlangga.

Soemirat S, Ardianto E. 2007. Dasar-dasar Public Realitions. Jakarta : Rosdakarya.

Soemirat S, Ardianto E. 2007. Dasar-Dasar Public Relations. Jakarta : Rosdakarya.
Soemirat, Soleh, \& Ardianto, Elvinaro (2007). Sugiyono, 2015. Metode Penelitian Kuantitatif dankualitatif. Alfabeta. Bandung

Sujarweni, Wiranata.V.2020. Metodologi Penelitian. Yogyakarta: PT PUSTAKA BARU

Undang-Undang Nomor 12 Tahun 2013 Tentang Pendidikan Tinggi

Undang-Undang Nomor 20 Tahun 2003 Tentang Sistem Pendidikan Nasional.

Usman, Irvan. 2013. Kepribadian, Komunikasi, Kelompok Teman Sebaya, IklimSekolah dan Perilaku Bullying. Humanitas, 10 (1): 49-6o.

Yusuf,Syamsul. 2009. Psikologi Perkembangan Anak dan Remaja. Bandung : PT. Remaja Rosdakarya 